\title{
Seasonal variation in the allergenic potency of airborne grass pollen in Bratislava (Slovakia) urban environment
}

\author{
Jana Ščevková ${ }^{1}$ (1) $\cdot$ Zuzana Vašková $^{1} \cdot$ Regina Sepšiováá $^{2}$. Jozef Kováč ${ }^{3}$ \\ Received: 3 May 2021 / Accepted: 24 June 2021 / Published online: 1 July 2021 \\ (C) The Author(s), under exclusive licence to Springer-Verlag GmbH Germany, part of Springer Nature 2021
}

\begin{abstract}
The Phl p 5 allergen of the plant species Phleum pratense is considered one of the most crucial grass pollen allergenic molecules inducing respiratory allergies. In this study, we evaluated seasonal variation in the concentration of both grass pollen and Phl p 5 allergens as well as the ratio allergen/pollen (pollen potency) in the air of Bratislava during two consecutive years, 2019-2020. These 2 years differed in terms of air pollution, as COVID-19 lockdown in spring 2020 considerably improved air quality in the study area. Air samples were collected using a Hirst-type sampler for pollen detection and the cyclone sampler for aeroallergen detection. In 2020, we observed $80.3 \%$ higher seasonal pollen integral, probably associated with the longer pollen season duration, however, $43.6 \%$ lower mean daily pollen potency than in 2019. The mean daily pollen value was $37.5 \%$ higher in 2020 than in the previous year, while the mean daily allergen value was $14.9 \%$ lower in 2020 . To evaluate the relationship between the amount of pollen or allergen in the air and selected meteorological factors and air pollution parameters, we used multiple regression analysis. Regarding weather factors, precipitation and relative humidity were significantly associated with pollen and/or allergen concentration, though these associations were negative. Atmospheric pollutants, especially $\mathrm{CO}, \mathrm{NO}_{2}$ and $\mathrm{O}_{3}$ were significantly associated with pollen and/or allergen levels. The associations with $\mathrm{CO}$ and $\mathrm{O}_{3}$ were positive, while the association with $\mathrm{NO}_{2}$ was negative. Our results indicate that for grasses, an air pollutant that has a significant positive relationship to the ratio of allergen/pollen is nitrogen dioxide.
\end{abstract}

Keywords $\mathrm{Phl}$ p 5 allergen $\cdot$ Poaceae pollen $\cdot$ Pollen potency $\cdot$ Air pollutants $\cdot$ Weather variables

\section{Introduction}

The number of people suffering from seasonal allergic respiratory disease is constantly increasing, especially in urbanised environments (D'Amato et al. 2007). The grasses (family Poaceae) belong to the group of phytoallergens as they produce allergenic pollen grains. Due to high species diversity of

Responsible Editor: Lotfi Aleya

Jana Ščevková

jana.scevkova@uniba.sk

1 Faculty of Natural Sciences, Department of Botany, Comenius University, Révová 39, 81102 Bratislava, Slovakia

2 Faculty of Natural Sciences, Department of Genetics, Comenius University, Ilkovičova 6, 84248 Bratislava, Slovakia

3 Faculty of Mathematics, Physics and Informatics, Department of Applied Mathematics and Statistics, Comenius University, Mlynská dolina, 84248 Bratislava, Slovakia this plant family (more than 10,000 species), their cosmopolitan distribution and the cross-reactivity among various grass species (Beggs et al. 2015), grass pollen is among the most dangerous pollen allergens in the world. In Bratislava, grasses are responsible for most pollinosis incidence in pollen-allergic individuals (Ščevková et al. 2015).

$\mathrm{Phl} \mathrm{p} \mathrm{5,} \mathrm{a} \mathrm{major} \mathrm{allergen} \mathrm{of} \mathrm{the} \mathrm{Phleum} \mathrm{pratense} \mathrm{pollen,} \mathrm{is}$ one of the most aggressive allergens of grasses (Esch 2008) and is responsible for almost $90 \%$ of pollinosis cases in European countries (Heinzerling et al. 2009).

The severity of the allergic symptoms depends on the size of intact pollen grains or smaller pollen-related allergen-bearing particles and in part on both the duration and intensity of pollen exposure (Ianovici 2007). Grass pollen grains (35-65 $\mu \mathrm{m})$ are too big to reach lower airways and therefore are captured in higher airways where they trigger common manifestations of allergic rhinitis. In contrast, airborne allergenic molecules released from grass pollen (Wang et al. 2012) are small enough $(0.6-2.5 \mu \mathrm{m})$ to penetrate the lower respiratory tract and cause severe allergic symptoms, e.g. allergic asthma. 
Most grass species are anemophilous and produce a large amount of well buoyant pollen grains (Prieto-Baena et al. 2003). Grasses are abundant in the territory of Bratislava, and the peak daily pollen levels reach more than 200 pollen/ $\mathrm{m}^{3}$ (Ščevková et al. 2010). This is more than six times higher than the threshold value $\left(30\right.$ pollen $\left./ \mathrm{m}^{3}\right)$, above which the symptoms of grass pollen allergy occur for sensitive individuals (Juhász et al. 2005).

The effects of allergenic pollen on the development of pollinosis in susceptible individuals are well known, but how the atmospheric environment affects these particles and how individual environmental factors influence their anatomical, physiological or morphological properties are not yet well documented. Air pollutants, such as e.g. particulate matter (PM), $\mathrm{O}_{3}, \mathrm{CO}, \mathrm{NO}_{2}$, might impact not only the release of allergens from pollen (D'Amato et al. 2015; Naclerio et al. 2020) but may also influence their allergenic potential through a greater expression of allergens in pollen. In this way, plants adapt to abiotic stress (Mousavi et al. 2019), with pollutants being among the major stressors, especially in urbanised environments (Suárez-Cervera et al. 2008). Moreover, it is demonstrated that pollen allergies appear to be more prevalent in polluted areas, especially areas with heavy traffic (Lucas et al. 2019). However, in 2020, the air quality substantially improved in numerous countries due to the COVID-19 lockdown accompanied by restricted movement of the public and shut down of industrial establishments (Dantas et al. 2020; Rathore et al. 2021). In Slovakia, the first phase of COVID-19 lockdown came into force on March 16, 2020, which later continued in the next phases. Therefore, this study focuses on the observation of the seasonal variation in the concentration of grass pollen and $\mathrm{Phl} p 5$ allergen in the air of Bratislava, as well as the ratio of allergen/pollen during 2 years characterised by a different level of air pollution. Moreover, the effect of weather and air pollution parameters on airborne pollen and allergen levels was appraised.

\section{Materials and methods}

\section{Study area}

Bratislava is the Capital of Slovakia situated in the southwestern part of the country (Fig. 1). The city has approximately 430,000 inhabitants and its area is $367.9 \mathrm{~km}^{2}$. The climate is continental and has a moderate to warm character. Bratislava belongs to the warmest and driest parts of Slovakia with the highest mean monthly temperature of $21.2^{\circ} \mathrm{C}$ in July and an average annual precipitation total of $667 \mathrm{~mm}$ (1983-2019 average, data excerpted from the database of Meteorological observatory Mlynská dolina in Bratislava). The urban landscape and its surroundings consist of ruderal vegetation, forests, semi-natural communities of grasses and anthropomorphic habitats.

\section{Airborne pollen and allergen sampling and quantifying}

The research was carried out using two types of equipment, Hirst-type volumetric pollen trap (Burkard Manufacturing Co Ltd.) to evaluate grass pollen concentrations and Multi-vial Volumetric Cyclone Air Sampler (Burkard Manufacturing Co Ltd.) to evaluate Phl p 5 allergen concentrations. The samplers were placed on the rooftop of the building $\left(48^{\circ} 08^{\prime} 58^{\prime \prime} \mathrm{N}\right.$, $17^{\circ} 04^{\prime} 24^{\prime \prime} \mathrm{E}, 18 \mathrm{~m}$ a.g.l). The Hirst sampler is operating since 2002 for the Slovak Aerobiological Network, while Multi-vial Cyclone Sampler is operating since 2019. The aerobiological survey was conducted from March to October 2019 and 2020.

The air intake rate of the Hirst sampler is $10 \mathrm{l} / \mathrm{min}$. The air that is drawn into the device impacts a drum covered with adhesive tape. The drum, mounted on a clock, rotates at a speed rate of $2 \mathrm{~mm} / \mathrm{h}$, and it makes one complete revolution in 7 days. Once a week, the exposed tape is cut into segments, each corresponding to 1-day exposure and microscopic slides are prepared. Afterwards, the slides are analysed under the light microscope at $\times 400$ magnification, according to Galán et al. $(2007,2014)$. Daily Poaceae pollen concentrations were expressed as a number of pollen grains per cubic metre of air $\left(\right.$ pollen $/ \mathrm{m}^{3}$ ). All identified grass pollen grains were presented as one taxon, i.e. the Poaceae family.

The Multi-vial Cyclone is a volumetric device with an airflow rate of $16 \mathrm{l} / \mathrm{min}$. After spiral movement of the air, which was suctioned into the cyclone, separated particles are conducted to 1.5-ml Eppendorf vials. There are 8 Eppendorf vials placed on a carousel and a rotation system that permits each vial to sample the air $24 \mathrm{~h}$ each day. The equipment ensures comparability of allergen and pollen data (Emberlin and Baboonian 1995). Airborne samples were collected dry and stored at $-20{ }^{\circ} \mathrm{C}$ until extraction, which was implemented according to Plaza et al. (2016). Airborne Phl p 5 allergen was enumerated by double-sandwich ELISA assay according to Ščevková et al. (2020). Daily allergen concentrations were expressed in picograms per cubic metre of air $\left(\mathrm{pg} / \mathrm{m}^{3}\right)$.

Allergenic particles of pollen origin were collected from the air during the main grass pollen season (MPS), defined as a period between the first and last day with the mean daily pollen concentration equal to or greater than 10 pollen $/ \mathrm{m}^{3}$ (Peel et al. 2014). The analyses of the day-to-day and yearly variations in airborne pollen and allergen concentrations were performed during the MPS, pre-peak and post-peak period. The period delimited by the start and peak day of the MPS is denoted pre-peak, whereas the period running from the peak day to the end of the MPS is denoted post-peak.

To calculate daily values of grass pollen potency (allergen release per pollen), the daily allergen concentrations were 
Fig. 1 Location of Bratislava in Slovakia (Central Europe)

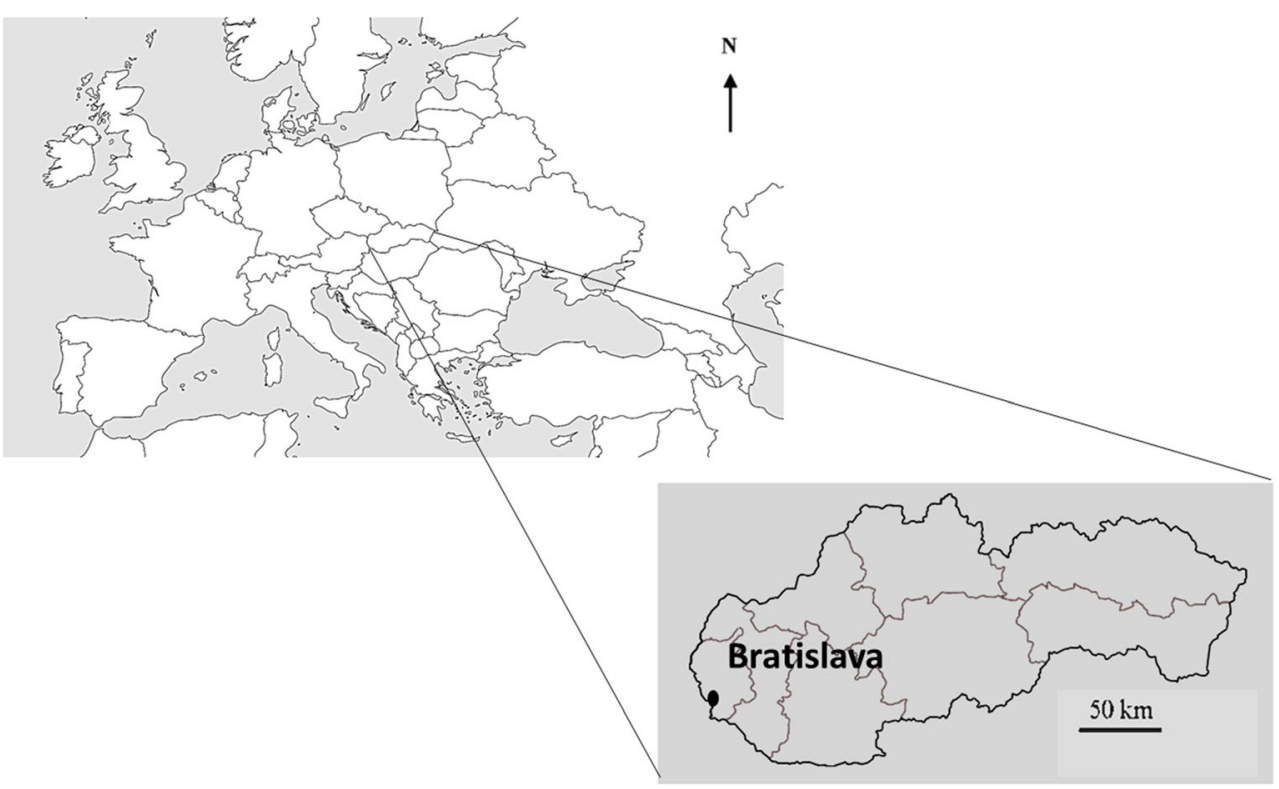

divided by daily pollen concentrations and expressed as pg Phl p 5/pollen (Ščevková et al. 2020).

\section{Environmental data}

To analyse the impact of weather variables on daily airborne pollen and allergen levels, the following weather parameters were considered: surface air temperature in ${ }^{\circ} \mathrm{C}$ (daily minimum, mean and maximum values), sunshine in hours (daily totals), relative humidity in percentage (daily mean values), wind speed in $\mathrm{m} / \mathrm{s}$ (daily mean values), air pressure in $\mathrm{hPa}$ (daily mean values), precipitation in $\mathrm{mm}$ (daily totals). Meteorological data were provided from the Meteorological Observatory of the Comenius University in Bratislava ( $48^{\circ} 09^{\prime}$ $\left.04^{\prime \prime} \mathrm{N}, 17^{\circ} 04^{\prime} 14^{\prime \prime} \mathrm{E}\right)$ located in the vicinity of the monitoring station.

To evaluate the influence of air pollution on airborne pollen and allergen levels, daily values of the following pollutants were considered: $\mathrm{PM}_{10}$-particulate matter $\leq 10 \mu \mathrm{m}\left(\mu \mathrm{g} / \mathrm{m}^{3}\right)$, $\mathrm{O}_{3}$ - ozone $\left(\mu \mathrm{g} / \mathrm{m}^{3}\right), \mathrm{NO}_{2}$ - nitrogen dioxide $\left(\mu \mathrm{g} / \mathrm{m}^{3}\right)$ and $\mathrm{CO}$ - carbon monoxide $\left(\mu \mathrm{g} / \mathrm{m}^{3}\right)$. The provider of air pollution data was the Slovak Hydrometeorological Institute (SHMÚ), the operator of the air quality monitoring units in Slovakia.

\section{Statistical analysis}

Nonparametric Spearman correlation analysis was performed to evaluate statistical correlations between airborne pollen and allergen concentrations. To investigate the effects of the environmental variables on the airborne pollen, allergen concentrations and pollen potency, we applied multiple regression analyses based on stepwise variable selection in the statistical software R (version 4.0.3). To adjust for the normality of residuals, response variables were log-transformed and to correct for autocorrelation of the measurements, autoregressivemoving average (ARMA) correlation structure was selected for the models by using the function $g l s$ from the nlme package. The autoregressive and the moving average orders were determined from the residuals of the regression model that did not allow for correlation in the observations. For airborne pollen, allergen concentrations and pollen potency, regression models containing all considered explanatory variables were fitted and insignificant variables ( $p$-value $>0.05$ ) were sequentially removed from the model. This analysis was performed for both years separately.

\section{Results}

The weather was different in the years of our study, during the period from 1 April to 31 July (Table 1), the period relevant to grass pollen development. The year 2019 was warmer in that period, received more precipitation but less sunshine and had a higher wind speed than 2020. April and May 2019 were colder and received more rainfall, whereas June in the same year was much warmer and drier than in 2020 (See Supplementary Materials, Table S1). The average temperatures in April and May 2019 were 0.5 and $1.2{ }^{\circ} \mathrm{C}$ lower than in the same month of the following year, reaching 12 and 12.6 ${ }^{\circ} \mathrm{C}$, respectively. In contrast, the temperature in June 2019 with the mean value of $23.3{ }^{\circ} \mathrm{C}$ was $4.7{ }^{\circ} \mathrm{C}$ higher than in 2020. The highest rainfall values were observed in May $2019(260.6 \mathrm{~mm})$ and June $2020(209.9 \mathrm{~mm})$, which is 57.1 and $91.2 \%$ higher, respectively, than in the same month in the neighbouring year. 
Table 1 Meteorological parameters and air pollutants in Bratislava in 2019 and 2020 (data are presented as averages from 1 April to 31 July)

\begin{tabular}{lll}
\hline Variables & 2019 & 2020 \\
\hline Meteorological parameters & & \\
Minimum air temperature $\left({ }^{\circ} \mathrm{C}\right)$ & 12.2 & 10.8 \\
Mean air temperature $\left({ }^{\circ} \mathrm{C}\right)$ & 17.5 & 16.5 \\
Maximum air temperature $\left({ }^{\circ} \mathrm{C}\right)$ & 22.7 & 22.4 \\
Sunshine $(\mathrm{h})$ & 7.6 & 8.1 \\
Atmospheric pressure $(\mathrm{hPa})$ & 992.7 & 994.1 \\
Relative air humidity $(\%)$ & 64.4 & 61.6 \\
Precipitation $(\mathrm{mm})$ & 99.8 & 92.8 \\
Wind speed (m/s) & 1.7 & 1.5 \\
Atmospheric pollutants* & & \\
Carbon monoxide & 339.8 & 251.1 \\
Nitrogen dioxide & 18.9 & 16.6 \\
Particulate matter $\leq 10 \mu \mathrm{m}$ & 21.3 & 18.1 \\
Ozone & 79.2 & 73.2 \\
\hline
\end{tabular}

*Values in micrograms per cubic metres

Regarding air pollutants, the April-July period in 2020 was characterised by a drop in the concentration of all air pollutants considered compared with the same period of the previous year (Table 1). The most significant decline was observed for $\mathrm{CO}, \mathrm{PM}_{10}$ and $\mathrm{NO}_{2}$ which concentrations were $26.1,15.0$ and $12.2 \%$ lower, respectively, in 2020 than in 2019. The decrease in ozone concentration was less pronounced; its concentration was $7.6 \%$ lower in 2020 than in the same period of the previous year. The most noticeable decline in $\mathrm{CO}$ and $\mathrm{NO}_{2}$ concentrations, which accounted for 30.2 and 21.8\%, respectively, was registered in May 2020, with the mean values of $247.2 \mu \mathrm{g} / \mathrm{m}^{3}$ for $\mathrm{CO}$ and $15.1 \mu \mathrm{g} /$ $\mathrm{m}^{3}$ for $\mathrm{NO}_{2}$ (see Supplementary Materials, Table S2). On the other hand, the most distinct decrease of $\mathrm{PM}_{10}(37 \%)$ and $\mathrm{O}_{3}$ (23\%) levels were observed in June 2020, with the mean values of $15 \mu \mathrm{g} / \mathrm{m}^{3}$ for $\mathrm{PM}_{10}$ and $65.7 \mu \mathrm{g} / \mathrm{m}^{3}$ for $\mathrm{O}_{3}$.

Table 2 shows the characteristics of both grass pollen and Phl p 5 allergen seasons associated with the analysed periods. In 2019, the MPS started on 11 May, which is 9 days later than in 2020 and it is also one of the most delayed start days of the grass pollen season in the last 19 years (Fig. 2). In 2020, MPS lasted 83 days (from 2 May to 23 July), while in 2019, the season was 21 days shorter (from 11 May to 11 July) than in the previous year (Table 2, Fig. 2). In 2020, the seasonal pollen integral over the MPS (SPIn) counted up to $1,830 \mathrm{pollen} / \mathrm{m}^{3}$, while in 2019 the SPIn $\left(1,015 \mathrm{pollen} / \mathrm{m}^{3}\right)$ was 80.3 and $36.7 \%$ lower than in 2020 and the long-term average, respectively (Table 2, Fig. 2). Even mean daily pollen values were $37.5 \%$ higher in 2020 than in the previous year. On the other hand, the Seasonal Allergen Integral amounted to $3,552 \mathrm{pg} / \mathrm{m}^{3}$ in 2020 represents only a $13.9 \%$ increase than in 2019. Moreover, mean daily allergen values
Table 2 Main pollen-season-related characteristics of grass pollen seasons in Bratislava, years 2019 and 2020

\begin{tabular}{lll}
\hline Characteristics & $2019 *$ & 2020 \\
\hline Grass pollen & & \\
Pollen season start & 11 May & 2 May \\
Pollen season end & 11 July & 23 July \\
Season length (days) & 62 & 83 \\
Seasonal pollen integral $\left(\mathrm{pollen} / \mathrm{m}^{3}\right)$ & 1,015 & 1,830 \\
Peak value (pollen $\left./ \mathrm{m}^{3}\right)$ & 81 & 182 \\
Peak day & 1 June & 23 June \\
Mean daily value $\left(\mathrm{pollen} / \mathrm{m}^{3}\right)$ & 16 & 22 \\
Phl p 5 allergen & & \\
Seasonal allergen integral $\left(\mathrm{pg} / \mathrm{m}^{3}\right)$ & 3,119 & 3,552 \\
Peak value $\left(\mathrm{pg} / \mathrm{m}^{3}\right)$ & 305.1 & 207.0 \\
Peak day & $1 \mathrm{June}$ & $2 \mathrm{June}$ \\
Mean daily value $\left(\mathrm{pg} / \mathrm{m}^{3}\right)$ & 50.3 & 42.8 \\
Pollen potency $(\mathrm{pg} / \mathrm{pollen}) * *$ & 5.5 & 3.1 \\
\hline
\end{tabular}

*Data in this column are reproduced from Ščevková et al. (2020)

**Mean daily value

were $14.9 \%$ lower in 2020 than in the preceding year. Last but not least, the peak pollen value was $124.7 \%$ higher in 2020, whereas the peak allergen value was $32.2 \%$ lower this year than in 2019 (Fig. 3). The mean pollen potency (allergen release per pollen) was $43.6 \%$ higher in 2019 than in 2020 (Table 2, Fig. 4).

Based on Spearman's correlation analysis results, positive associations between the pollen and allergen levels were observed for the pre-peak period $\left(r_{s}=0.495, p<0.001\right)$, MPS $\left(r_{s}\right.$ $=0.503, p<0.001)$ and the post-peak period $\left(r_{s}=0.521, p<\right.$ 0.001 ) in 2020, while in 2019 the significant positive association was noted only for the pre-peak period $\left(r_{s}=0.542, p<\right.$ 0.01) (Table 3).

Results of multiple regression analysis, which was accomplished to determine the impact of weather variables and air pollutants on airborne pollen and allergen levels and pollen potency, are presented in Table 4. Based on our results, precipitation and relative air humidity were the most influential weather variables. Relative air humidity was negatively associated with allergen or pollen concentration, whereas precipitation was negatively associated only with pollen concentration. The meteorological parameter that has a significant relationship to the ratio of allergen/pollen is sunshine, though this association was negative.

Among the atmospheric pollutants, $\mathrm{CO}$ and $\mathrm{NO}_{2}$ were significantly interrelated with pollen and allergen levels. The relationship with $\mathrm{CO}$ was positive, whereas a negative association with $\mathrm{NO}_{2}$ was observed. Furthermore, a significant positive relationship between $\mathrm{NO}_{2}$ and pollen potency was observed in 2020 . Ozone was significantly and positively associated with pollen concentration in 2019 , whereas a significant 
Fig. 2 The characteristics of the grass main pollen seasons (SPIn, season start, season length) in Bratislava over the long-term period; SPIn (pollen $/ \mathrm{m}^{3}$ ) - seasonal pollen integral (sum of the average daily pollen concentrations recorded over the Main pollen season); season start (DOY - the day of the year from 1 January); season length (days)

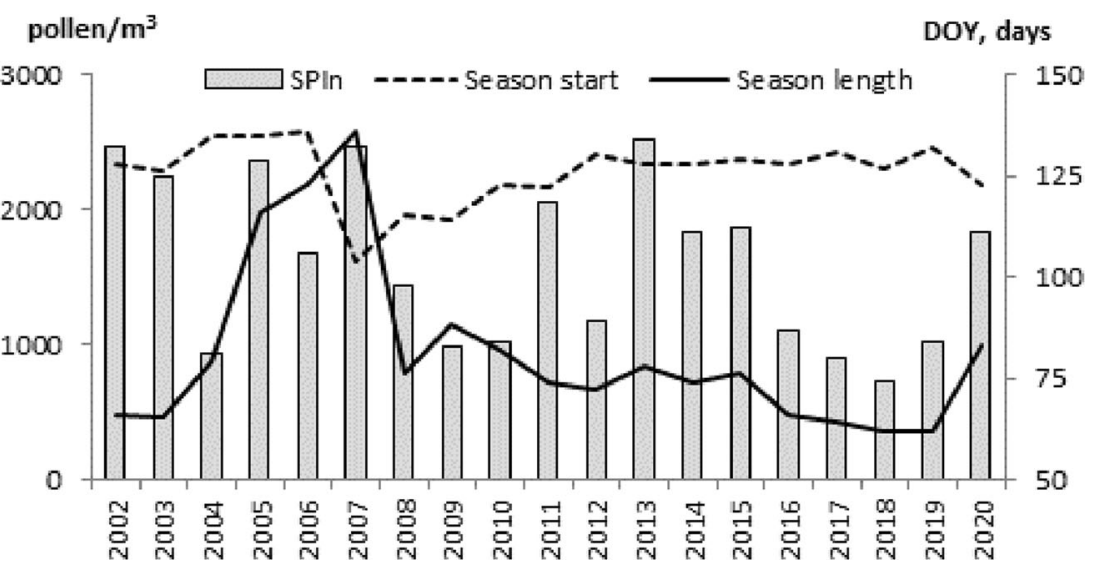

negative relationship between this air pollutant and pollen potency was noted in 2020.

Environmental parameters have explained from 19.1 to $47.1 \%$ of the total variance for airborne pollen or allergen levels and $26.1 \%$ for pollen potency (Table 4 ).

\section{Discussion}

In support of the importance of determining the allergenicity of pollen grains, the simple count of pollen grains does not always correlate with the prevalence of pollen respiratory allergy events (Buters 2012). The reason is that pollen allergens are associated not only with intact pollen but may also be found in smaller pollen-derived airborne respirable particles. Our study revealed positive relationships between the airborne pollen and allergen levels in both years; though, these associations were not significant for the Main pollen season (MPS) and the post-peak period in 2019. The occurrence of several discrepancy episodes in 2019, particularly during the postpeak period, seems to be a reason for lacking a significant relationship between airborne pollen and allergen concentrations during both the MPS and the post-peak period. Based on our results, allergen levels could be explained with the pollen concentrations but only for the year 2020. Significant positive relationships between grass pollen levels and the levels of $\mathrm{Phl}$ p 5 allergens have also been reported by Plaza et al. (2016). Similarly to our results, days with low airborne pollen but high allergen levels and reversely were noted by several other researchers (e.g. Rodríguez-Rajo et al. 2011). In this regard, it is relevant to note that airborne pollen levels depend on the blooming period and its intensity (Galán et al. 2016).
Fig. 3 The airborne levels of Poaceae pollen and Phl p 5 allergen in Bratislava over the main pollen seasons, years 2019 2020

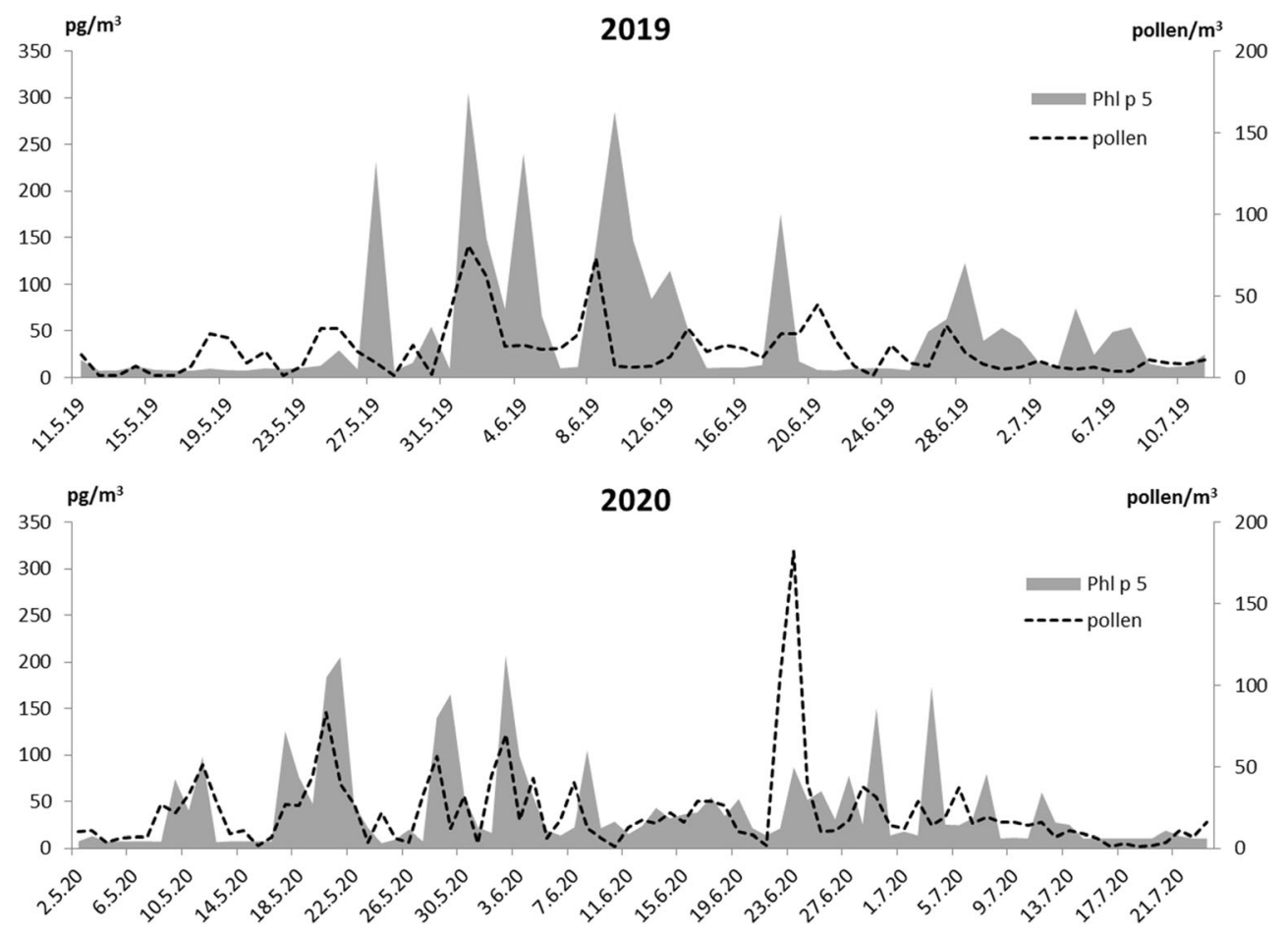


Fig. 4 Allergenic potency of grass pollen in Bratislava in 2019 and 2020

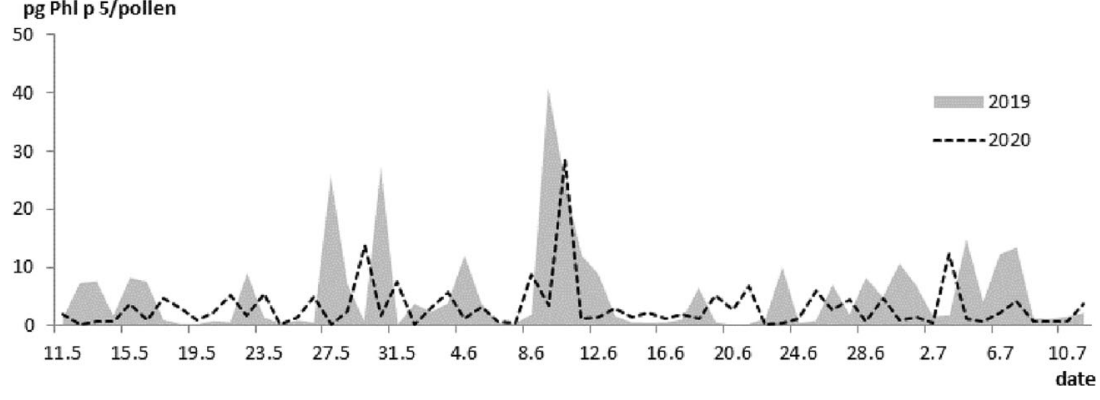

However, smaller pollen-derived particles containing allergens can vary in the atmosphere depending on pollen as a source of particles and different environmental factors. For this reason, the pollen potency, defined as the allergen release capacity of any pollen grain in the study area (Canini et al. 2004), was evaluated in this present study. Interestingly, despite the substantially higher intensity of grass pollen season in 2020, indicated by a higher SPIn, mean daily pollen values and peak pollen value, only a slight increase in seasonal allergen integral (SAIn) was observed. Similarly to our results, years with higher SPIn of grasses but lower SAIn of Phl p 5 and vice versa were also noted by Plaza et al. (2016), who consider air pollutants as stressors associated with a decrease in flowering intensity. Subsequent lower pollen production per inflorescence accompanied by higher allergen content, the mentioned researchers considered a strategy of plants to ensure the efficiency of the pollination process. Besides, we observed a seasonal variation in average daily pollen potency values that accounted for $5.7 \mathrm{pg} / \mathrm{m}^{3}$ in 2019 and $3.1 \mathrm{pg} / \mathrm{m}^{3}$ in 2020. This discrepancy is probably because of the different weather conditions as it was seen that during the 2019 pollen season characterised by a more humid spring, the pollen potency was higher than in 2020, a year with drier spring. This fact proves the influence of meteorological conditions on the release of allergens from pollen grains (Buters et al. 2015).

The internal biological agents and external environmental parameters, including weather variables, can affect grass pollen concentration in the atmosphere and pollen season length (Plaza et al. 2016). Our study shows that if the spring is humid, as it was found in 2019, it prevents pollen grains from being released from the anthers, and the start of the MPS is delayed. On the other hand, if the beginning of summer is warm and

Table 3 Spearman's correlation coefficients between the quantity of airborne grass pollen and Phl p 5 allergen in Bratislava during the MPS, pre-peak and post-peak periods

\begin{tabular}{llll}
\hline Year & Pre-peak & MPS & $\begin{array}{l}\text { Post- } \\
\text { peak }\end{array}$ \\
\hline 2019 & $0.542^{* *}$ & 0.202 & 0.002 \\
2020 & $0.495^{* * *}$ & $0.503 * * *$ & $0.521^{* * *}$ \\
\hline
\end{tabular}

$* * p<0.01 ; * * * p<0.001$ dry, pollen concentration may be reduced to a minimum due to pollen depletion, shortening the MPS as it was seen in 2019.

In general, high airborne grass pollen concentrations are associated with warm and dry days (Plaza et al. 2020). However, the significant relationships observed in the present study were only those between airborne pollen concentration and precipitation or relative air humidity, albeit the relationships were negative. Variations in air humidity affect the emission and airborne dispersion of pollen, either because the anthers are moist and cannot release the pollen or because the pollen grains, once in the air, become partially hydrated and disperse scarcely. On the other hand, precipitation removes pollen grains from the atmosphere by wash-out mechanism (Lacey 1986).

Besides pollen grains, meteorological parameters may also influence the presence of pollen-derived allergenic molecules in the ambient air. The pollen exine can be broken by high humidity, causing the release of its inner contents, including allergic molecules (Silva et al. 2015). Several researchers, i.e. Rodríguez-Rajo et al. (2011), confirmed the ability of humid weather to release allergenic molecules from pollen grains, especially from those with thin and delicate walls, as is grass pollen due to osmotic shock (Buters et al. 2015). The present study found relative air humidity to be a significant, though negative factor elucidating the variability in airborne allergen levels. The lack of positive correlation is presumably due to the increased sedimentation velocity of humid pollen-derived fragments containing allergens due to their altered weight, density and aerodynamic properties (Alan et al. 2018). This is, however, in contrast with the other research studies (e.g. Buters et al. 2008; Plaza et al. 2016), where no relationship between meteorological parameters and the allergen concentration in the atmosphere was observed.

Aside from pollen production, the release of pollen grains from anthers and its dispersal in the atmosphere (FernándezGonzález et al. 2011), days with high air temperature is also known to be associated with increased expression of allergens in the pollen grains of seed plants, especially in the urban areas (Tashpulatov et al. 2004; D'Amato et al. 2007). We observed a higher airborne pollen concentration and release of $\mathrm{Phl} p 5$ allergen from grass pollen when the temperature was higher, especially during the pre-peak period; however, this weather 
Table 4 Significant environmental variables in multiple regression models for grass pollen, Phl $\mathrm{p} 5$ allergen and pollen potency

\begin{tabular}{|c|c|c|c|c|c|c|}
\hline Year & & Variables & $\beta$ Coeff. & Std. error & $p$-value & $R^{2}$ \\
\hline \multirow[t]{10}{*}{2019} & \multirow[t]{5}{*}{ Pollen } & Intercept & -3.6962 & 1.2811 & 0.0055 & \multirow[t]{5}{*}{0.4709} \\
\hline & & Precipitation & -0.0360 & 0.0129 & 0.0072 & \\
\hline & & Ozone & 0.0340 & 0.0080 & $<0.0001$ & \\
\hline & & Carbon monoxide & 0.0149 & 0.0036 & 0.0001 & \\
\hline & & Nitrogen dioxide & -0.0838 & 0.0383 & 0.0329 & \\
\hline & \multirow[t]{4}{*}{ Allergen } & Intercept & 4.6177 & 1.0772 & $<0.0001$ & \multirow[t]{4}{*}{0.2465} \\
\hline & & Relative humidity & -0.0459 & 0.0114 & 0.0002 & \\
\hline & & Carbon monoxide & 0.0113 & 0.0047 & 0.0184 & \\
\hline & & Nitrogen dioxide & -0.1221 & 0.0478 & 0.0133 & \\
\hline & Pollen potency & $\mathrm{ns}$ & & & & \\
\hline \multirow[t]{7}{*}{2020} & \multirow[t]{2}{*}{ Pollen } & Intercept & 5.7262 & 0.5224 & $<0.0001$ & \multirow[t]{3}{*}{0.1907} \\
\hline & & Relative humidity & -0.0463 & 0.0073 & $<0.0001$ & \\
\hline & Allergen & ns & & & & \\
\hline & \multirow[t]{4}{*}{ Pollen potency } & Intercept & 2.0888 & 0.5643 & 0.0004 & \multirow[t]{4}{*}{0.261} \\
\hline & & Sunshine & -0.1054 & 0.0342 & 0.0028 & \\
\hline & & Ozone & -0.0189 & 0.0095 & 0.0499 & \\
\hline & & Nitrogen dioxide & 0.0445 & 0.0205 & 0.0329 & \\
\hline
\end{tabular}

$n s$ no significant variables

parameter did not show statistically significant associations with the grass pollen or Phl p 5 aeroallergen concentrations. On the other hand, a significant relationship between the allergen/pollen ratio and sunshine was observed in our study, though this relationship was negative. We presume that UV radiation from sunlight inhibits the secretion of allergen in pollen grains. However, further research is needed to be done to prove this presumption.

Atmospheric pollutants are known to affect pollen grains differently, altering either pollen morphology or protein content (Sénéchal et al. 2015). The main focus of the recent environmental studies is on the effect of the atmospheric pollutants on the expression of allergological-important pollen proteins as the content of these molecules was found to be greater in pollen collected from polluted than unpolluted areas (Armeria et al. 2002). In this context, we observed more intensive aeroallergen season in 2019, manifested by higher mean daily Phl p 5 allergen concentrations and mean daily pollen potency as well as a higher peak allergen value than in 2020, which could be associated, besides other factors, with a higher rate of air pollution in 2019 (D'Amato et al. 2007). Even though the decrease in pollen potency in 2020 may merely indicate an unrelated trend in time, we speculate that it may have been influenced by declined atmospheric pollution in Bratislava due to the COVID-19 lockdown. It improved substantially air quality in Bratislava due to a significant decline of the $\mathrm{CO}, \mathrm{NO}_{2}$ and $\mathrm{PM}_{10}$ levels and a moderate reduction of $\mathrm{O}_{3}$ levels. Improving air quality due to lockdown has been observed in numerous countries (e.g. Mahato et al. 2020; Dantas et al. 2020; Wang et al. 2020).
There is a significant positive relationship between aeroallergens and airborne pollen levels during the MPS in 2020, so allergen concentrations could be explained with the pollen concentrations. However, the situation was different in 2019, without a significant association between airborne allergen and pollen levels during the MPS. Considering our results, pollutants, especially $\mathrm{CO}$, may affect aeroallergen concentrations since a positive relationship between the mentioned variables was observed in Bratislava. The emission of $\mathrm{CO}$ and $\mathrm{NO}_{2}$, one of the main sources of atmospheric contaminants in Bratislava, is primarily associated with the combustion process of fuel like gasoline and diesel in vehicles and industries (Frank and Ernst 2016). In this study, it is shown that $\mathrm{CO}$ and $\mathrm{NO}_{2}$ pollutants affect airborne grass pollen or allergen concentrations differently. Besides a significant positive relationship of the pollen and allergen content with $\mathrm{CO}$, a significant negative association between $\mathrm{NO}_{2}$ and pollen/ allergen levels was observed.

Carbon monoxide, a regulator of multiple biological processes in plants, acts as a signalling molecule during plant growth and development and interacts with other signalling molecules in plant stress response (Lin et al. 2014; Xie et al. 2014). Similarly to other air pollutants, CO could enhance the number of allergens in pollen grains attributed to the adaptation of plants to abiotic stress (Shahali and Dadar 2018; Mousavi et al. 2019). It is in line with our results since we observed increased $\mathrm{Phl}$ p 5 aeroallergen levels accompanied by ascended $\mathrm{CO}$ levels in the atmosphere.

Nitrogen dioxide can negatively affect either the development of plants or their blooming period and, consequently, 
reduce pollen production. In this regard, we noted decreased airborne pollen and allergen concentrations accompanied by decreasing $\mathrm{NO}_{2}$ levels. However, the results of studies analysing the influence of this atmospheric pollutant on allergen expressions in pollen are inconsistent. Several researchers (Bist et al. 2004; Sousa et al. 2012; Hong et al. 2018) pointed out, based on in vitro studies, that $\mathrm{NO}_{2}$ causes a general drop in allergenic protein content of exposed pollen grains. In contrast, we observed a significant positive relationship between pollen potency and $\mathrm{NO}_{2}$ levels. We suppose, similarly to Hong et al. (2018), who noted a decrease in the allergenicity of Hum $\mathrm{j} 1$ allergen of Humulus japonicus pollen after $\mathrm{NO}_{2}$ exposure, that the effect of this pollutant was probably overridden by ozone.

The tropospheric ozone is a secondary pollutant, which is produced by photochemical reactions between volatile organic compounds and nitrogen oxides (Frank, Ernest 2016). Warm sunny days were accompanied by the increased pollen and ozone levels in the atmosphere of Bratislava. Likewise, Puc (2011) in Szczecin (Poland), we noted a significant positive relationship between grass pollen and $\mathrm{O}_{3}$ levels in the air of the study area. Besides, ozone, an important stress factor for plants, should also be associated with a greater expression of allergens. Notwithstanding, this was not confirmed in our study. Similarly to Plaza et al. (2020), we indicated that ozone has even a significant negative relationship with grass pollen potency. However, this connection is probably due to the impact of weather conditions as air temperature and UV radiation affect ozone formation (Stathopoulou et al. 2008). Additionally, several other researchers (Eckl-Dorna et al. 2010; Frank and Ernst 2016) indicated that the exposure of grass pollen to increasing ozone concentrations resulted in a significant increase in the number of allergen-containing granules released from pollen. In these studies, however, plants were exposed to not natural but definite ozone levels.

\section{Conclusions}

In 2020, the year characterised by a less polluted atmosphere due to COVID-19 lockdown, we observed significantly higher seasonal Poaceae pollen integral, the mean daily pollen value and even peak pollen value, while the mean daily pollen potency, the mean daily allergen concentration and peak allergen value were significantly lower than in 2019 .

Raised pollen concentrations were accompanied by increased $\mathrm{O}_{3}$ and $\mathrm{CO}$ levels in 2019, whereas increased rainfall or relative humidity led to the reduction of pollen in the atmosphere. In 2020, the aeroallergen levels were associated mainly with pollen, but nitrogen dioxide in the air could increase the number of allergens per pollen. In contrast, the aeroallergen levels were in particular associated with carbon monoxide in 2019. Based on our results, it is evident that air pollutants can influence grass plants to produce pollen with altered allergenic content.

Supplementary Information The online version contains supplementary material available at https://doi.org/10.1007/s11356-021-15179-5.

Acknowledgments The authors acknowledge both the Division of Meteorology and Climatology (Faculty of Mathematics, Physics and Informatics of Comenius University in Bratislava) for providing meteorological data and the Slovak Hydrometeorological Institute (SHMÚ) for providing air pollution data used in this paper.

Author contribution Jana Ščevková: conceptualisation, formal analysis, methodology, supervision, validation, visualisation, writing - original draft, writing - review and editing. Zuzana Vašková: data curation, formal analysis, investigation, visualisation, writing - review and editing. Regina Sepšiová: formal analysis, methodology, validation, visualisation, writing - review and editing. Jozef Kováč: data curation, investigation, writing — review and editing

Funding This study was supported by Grant Agency VEGA (Bratislava) (Grant Nos. 1/0061/20 and 1/0180/22).

Data availability All data generated or analysed during this study are included in this published article and its supplementary information file.

\section{Declarations}

Ethics approval and consent to participate Not applicable.

Consent for publication Not applicable.

Competing interests The authors declare no competing interests.

\section{References}

Alan S, Sahin AA, Sarișahin T, Sahin S, Kaplan A, Pinar NM (2018) The effect of geographical and climatic properties on grass pollen and $\mathrm{Phl}$ p 5 allergen release. Int J Biometeorol 62:1325-1337. https:// doi.org/10.1007/s00484-018-1536-0

Armeria A, Lombardero M, Callejo A, Barber D, Gil FM, Martin-Santos J, Vega JM, Arranz ML (2002) Is Lolium pollen from an urban environment more allergenic than rural pollen? Allergol Immunopathol 30:218-224. https://doi.org/10.1016/S03010546(02)79124-6

Beggs PJ, Katelaris CH, Medek D, Johnston FH, Burton PK, Campbell B, Jaggard AK, Vicendese D, Bowman DMJS, Godwin I, Huete AR, Erbas B, Green BJ, Newnham RM, Newbigin E, Haberle SG, Davies JM (2015) Differences in grass pollen allergen exposure across Australia. Aust N Z J Public Health 39:51-55. https://doi. org/10.1111/1753-6405.12325

Bist A, Pandit T, Bhatnagar AK, Singh AB (2004) Variability in protein content of pollen of Castor bean (Ricinus communis) before and after exposure to the air pollutants $\mathrm{SO}_{2}$ and $\mathrm{NO}_{2}$. Grana 43:94 100. https://doi.org/10.1080/00173130410019316

Buters JTM (2012) Release of Bet v 1 from birch pollen from 5 European countries: results from the HIALINE study. Atmos Environ 55:496505. https://doi.org/10.1016/j.atmosenv.2012.01.054

Buters JTM, Kasche A, Weichenmeier I, Schober W, Klaus S, TraidlHoffmann C, Menzel A, Huss-Marp J, Krämer U, Behrendt H 
(2008) Year-to-year variation in release of Bet v 1 allergen from birch pollen: evidence for geographical differences between west and south Germany. Int Arch Allergy Immunol 145:122-130. https://doi.org/10.1159/000108137

Buters JTM, Prank M, Sofiev M, Pusch G, Albertini R, Annesi-Maesano I, Antunes C, Behrendt H, Berger U, Brandao R, Celenk S, Galan C, Grewling $€$, Jackowiak B, Kennedy R, Rantio-Lehtimäki A, Reese G, Sauliene I, Smith M, Thibaudon M, Weber B, Cecchi L (2015) Variation of the group 5 grass pollen allergen content of airborne pollen in relation to geographic location and time in season. J Allergy Clin Immunol 136:87-95. https://doi.org/10.1016/j.jaci. 2015.01.049

Canini A, Giovinazzi J, Ianovici P, Pini C, Caiola MG (2004) Localisation of carbohydrate epitope recognised by human IgE in pollen of Cupressaceae. J Plant Res 117:147-153. https://doi.org/10. 1007/s10265-003-0139-x

D’Amato G, Cecchi L, Bonini S, Nunes C, Annesi-Maesano I, Behrendt H, Liccardi G, Popov T, van Cauwenberge P (2007) Allergenic pollen and pollen allergy in Europe. Allergy 62:976-990. https:// doi.org/10.1111/j.1398-9995.2007.01393.x

D'Amato G, Holgate ST, Pawankar R, Ledford DK, Cecchi L, Al-Ahmad $M$ et al (2015) Meteorological conditions, climate change, new emerging factors, and asthma and related allergic disorders. A statement of the World Allergy Organization. World Allergy Organ J 8: 25. https://doi.org/10.1186/s40413-015-0073-0

Dantas G, Siciliano B, Franca BB, da Silva CM, Arbilla G (2020) The impact of COVID-19 partial lockdown on the air quality of the city of Rio de Janeiro, Brazil. Sci Total Environ 729:e139085. https:// doi.org/10.1016/j.scitotenv.2020.139085

Eckl-Dorna J, Klein B, Reichenauer TG, Niederberger V, Valenta R (2010) Exposure of rye (Secale cereale) cultivars to elevated ozone levels increases the allergen content in pollen. J Allergy Clin Immunol 126:1315-1317. https://doi.org/10.1016/j.jaci.2010.06. 012

Emberlin J, Baboonian C (1995) The development of a new method of sampling particles for immunological analysis, in Proceedings, XVI European Congress of Allergology and Clinical Immunology, 24 25

Esch RE (2008) Grass pollen allergens. Clin Allergy Immunol 21:101126

Fernández-González D, Rodriguez Rajo FJ, Gonzalez Parrado Z, Valencia Barrera R, Jato V, Grau SM (2011) Differences in atmospheric emissions of Poaceae pollen and Lol p 1 allergen. Aerobiologia 27:301-309. https://doi.org/10.1007/s10453-0119199-x

Frank U, Ernst D (2016) Effects of $\mathrm{NO}_{2}$ and ozone on pollen allergenicity. Front Plant Sci 7:e91. https://doi.org/10.3389/fpls.2016.00091

Galán C, Cariñanos P, Alcázar P, Domínguez-Vilches E (2007) Spanish aerobiology network (REA): management and quality manual. Servicio de publicaciones de la Universidad de Córdoba, Córdoba

Galán C, Smith M, Thibaudon M, Frenguelli G, Oteros J, Gehrig R et al (2014) Pollen monitoring: minimum requirements and reproducibility of analysis. Aerobiologia 30:385-395. https://doi.org/10.1007/ s10453-014-9335-5

Galán C, Alcázar P, Oteros P, García-Mozo H, Aira MJ, Belmonte J et al (2016) Airborne pollen trends in the Iberian Peninsula. Sci Total Environ 550:53-59. https://doi.org/10.1016/j.scitotenv.2016.01.069

Heinzerling LM, Burbach GJ, Edenharter G, Bachert C, Bindslev-Jensen C, Boini S (2009) GA ${ }^{2}$ LEN skin test study I: GA ${ }^{2}$ LEN harmonization of skin prick testing: novel sensitization patterns for inhalant allergens in Europe. Allery 64:1498-1506. https://doi.org/10.1111/j. 1398-9995.2009.02093.x

Hong Q, Zhou S, Zhao H, Peng J, Li Y, Shang Y, Wu M, Zhang W, Lu S, Li S, Yu S, Wang W, Wang Q (2018) Allergenicity of recombinant Humulus japonicus pollen allergen 1 after combined exposure to ozone and nitrogen dioxide. Environ Pollut 234:707-715. https:// doi.org/10.1016/j.envpol.2017.11.078

Ianovici N (2007) The principal airborne and allergenic pollen species in Timisoara. Annals of West University of Timisoara, ser. Biology 10: $11-26$

Juhász IE, Juhász M, Radišič P, Ianovici N, Sikoparija B (2005) Aerobiological importance of grasses in the DKMT Euroregion. In: The 12th Symposium on Analytical and Environmental Problems; 2005 Sep 26; Szeged, Hungary, 144-148

Lacey J (1986) Water availability and fungal reproduction: patterns of spore production, liberation and dispersal. In: Ayres PG, Boddy L (eds) Water, fungi and plants. Cambridge University Press, Cambridge, pp 65-86

Lin YT, Zhang W, Qi F, Cui WT, Xie YJ, Shen WB (2014) Hydrogenrich water regulates cucumber adventitious root development in a heme oxygenase-1/carbon monoxide-dependent manner. J Plant Physiol 171:1-8. https://doi.org/10.1016/j.jplph.2013.08.009

Lucas JA, Gutierrez Albanchez E, Alfaya T, Feo-Brito F, Gutierrez Mañero FJ (2019) Oxidative stress in ryegrass growing under different air pollution levels and IST likely effects on pollen allergenicity. Plant Physiol Biochem 135:331-340. https://doi.org/10. 1016/j.plaphy.2018.12.018

Mahato S, Pal S, Ghosh KG (2020) Effect of lockdown amid COVID-19 pandemic on air quality of the megacity Delhi, India. Sci Total Environ 730:e139086. https://doi.org/10.1016/j.scitotenv.2020. 139086

Mousavi F, Shahali Y, Pourpak Z, Majd A, Ghahremaninejad F (2019) Year-to-year variation of the elemental and allergenic contents of Ailanthus altissima pollen grains: an allergomic study. Environ Monit Assess 191:362. https://doi.org/10.1007/s10661-019-7458-4

Naclerio R, Ansotegui IJ, Bousquet J, Canonica GW, D'Amato G, Rosario N, Pawankar R, Peden D, Bergmann K-C, Bielory L et al (2020) International expert consensus on the management of allergic rhinitis (AR) aggravated by air pollutants: impact of air pollution on patients with AR: current knowledge and future strategies. World Allergy Organ J 13:e100106. https://doi.org/10.1016/j.waojou. 2020.100106

Peel RG, Ørby PV, Skjøth CA, Kennedy R, Schlünssen V, Smith M, Sommer J, Hertel O (2014) Seasonal variation in diurnal atmospheric grass pollen concentration profiles. Biogeosciences 11:821-832. https://doi.org/10.5194/bg-11-821-2014

Plaza MP, Alcázar P, Hernández-Ceballos MA, Galán C (2016) Mismatch in aeroallergens and airborne grass pollen concentrations. Atmos Environ 144:361-369. https://doi.org/10.1016/j.atmosenv. 2016.09.008

Plaza MP, Alcázar P, Oteros J, Galán C (2020) Atmospheric pollutants and their association with olive and grass aeroallergen concentrations in Córdoba (Spain). Environ Sci Pollut Res 27:45447-45459. https://doi.org/10.1007/s11356-020-10422-x

Prieto-Baena JC, Hidalgo PJ, Domínguez E, Galán C (2003) Pollen production in the Poaceae family. Grana 42:153-159. https://doi.org/ $10.1080 / 00173130310011810$

Puc M (2011) Threat of allergenic airborne grass pollen in Szczecin, NW Poland: the dynamics of pollen seasons, effect of meteorological variables and air pollution. Aerobiologia 27:191-202. https://doi. org/10.1007/s10453-010-9188-5

Rathore DS, Nagda C, Shaktawat B, Kain T, Chouhan CS, Purohit R, Harish KRK, Nagda G, Jhala LS (2021) COVID-19 lockdown: a boon in boosting the air quality of major Indian Metropolitan Cities. Aerobiologia 37:79-103. https://doi.org/10.1007/s10453-02009673-5

Rodríguez-Rajo F, Jato V, Gonzalez-Parrado Z, Elvira-Rendueles B, Moreno-Grau S, Vega-Maray A, Fernandez-Gonzalez D, Asturias JA, Suarez-Cervera M (2011) The combination of airborne pollen and allergen quantification to reliably assess the real pollinosis risk 
in different bioclimatic areas. Aerobiologia 27:1-12. https://doi.org/ 10.1007/s10453-010-9170-2

Ščevková J, Dušička J, Chrenová J, Mičieta K (2010) Annual pollen spectrum variations in the air of Bratislava (Slovakia): years 20022009. Aerobiologia 26:277-287. https://doi.org/10.1007/s10453010-9163-1

Ščevková J, Dušička J, Hrubiško M, Mičieta K (2015) Influence of airborne pollen counts and length of pollen season of selected allergenic plants on the concentration of $\operatorname{sgE}$ antibodies on the population of Bratislava, Slovakia. Ann Agric Environ Med 22:451-455. https:// doi.org/10.5604/12321966.1167712

Ščevková J, Vašková Z, Sepšiová R, Dušička J, Kováč J (2020) Relationship between Poaceae pollen and $\mathrm{Phl}$ p 5 allergen concentrations and the impact of weather variables and air pollutants on their levels in the atmosphere. Heliyon 6:e04421. https://doi.org/10. 1016/j.heliyon.2020.e04421

Sénéchal H, Visez N, Charpin D, Shahali Y, Peltre G, Biolley J-P, Lhuissier F, Couderc R, Yamada O, Malrat-Domenge A (2015) A review of the effects of major atmospheric pollutants on pollen grains, pollen content, and allergenicity. Sci World J 2015:1-29. https://doi.org/10.1155/2015/940243

Shahali Y, Dadar M (2018) Plant food allergy: influence of chemicals on plant allergens. Food Chem Toxicol 115:365-374. https://doi.org/ 10.1016/j.fct.2018.03.032

Silva M, Ribeiro H, Abreu I, Cruz A, Esteves da Silva JC (2015) Effects of $\mathrm{CO}_{2}$ on Acer negundo pollen fertility, protein content, allergenic properties, and carbohydrates. Environ Sci Pollut Res Int 22:6904 6911. https://doi.org/10.1007/s11356-014-3896-2

Sousa R, Duque L, Duarte AJ, Gomes CR, Ribeiro H, Cruz A, Silva JCGE, Abreu I (2012) In vitro exposure of Acer negundo pollen to atmospheric levels of $\mathrm{SO}_{2}$ and $\mathrm{NO}_{2}$ : effects on allergenicity and germination. Environ Sci Technol 46:2406-2412. https://doi.org/ $10.1021 /$ es 2034685
Stathopoulou E, Mihalakakou G, Santamouris M, Bagiorgas HS (2008) On the impact of temperature on tropospheric ozone concentration levels in urban environments. J Earth Syst Sci 117:227-236. https:// doi.org/10.1007/s12040-008-0027-9

Suárez-Cervera M, Castells T, Vega-Maray A, Civantos E, del Pozo V, Fernández-González D, Moreno-Grau S, Moral A, López-Iglesias C, Lahoz C, Seoane-Camba JA (2008) Effects of air pollution on Cup a 3 allergen in Cupressus arizonica pollen grains. Ann Allergy Asthma Immunol 101:57-66. https://doi.org/10.1016/S10811206(10)60836-8

Tashpulatov AS, Clement P, Akimcheva SA, Belogradova KA, Barinova I, Rakhmawaty FD, Heberle-Bors E, Touraev A (2004) A model system to study the environment-dependent expression of the Bet $\mathrm{v}$ 1a gene encoding the major birch pollen allergen. Int Arch Allergy Immunol 134:1-9. https://doi.org/10.1159/000077527

Wang Q, Nakamura S, Lu S, Xiu G, Nakajima D, Suzuki M, Sakamoto K, Miwa M (2012) Release behaviour of small sized daughter allergens from Cryptomeria japonica pollen grains during urban rainfall event. Aerobiologia 28:71-81. https://doi.org/10.1007/s10453-0119212-4

Wang M, Liu F, Zheng M (2020) Air quality improvement from COVID19 lockdown: evidence from China. Air Qual Atmos Health 14: 591-604. https://doi.org/10.1007/s11869-020-00963-y

Xie Y, Zhang C, Lai D, Sun Y, Samma MK, Zhang J, Shen W (2014) Hydrogen sulfide delays GA-triggered programmed cell death in wheat aleurone layers by the modulation of glutathione homeostasis and hemeoxygenase-1 expression. J Plant Physiol 171:53-62. https://doi.org/10.1016/j.jplph.2013.09.018

Publisher's note Springer Nature remains neutral with regard to jurisdictional claims in published maps and institutional affiliations. 